\title{
Shadow economies and tax evasion: The case of the Czech Republic, Poland and Hungary
}

\author{
DENNIS NCHOR*
}

Department of Economics, Faculty of Business and Economics, Mendel University, Brno, Czech Republic

Received: May 1,2020 • Revised manuscript received: October 19, 2020 • Accepted: October 26, 2020

Published online: December 2, 2020

(c) 2020 The Author(s)

\begin{abstract}
This paper examines the drivers and the size of the shadow economies of the Czech Republic, Hungary and Poland. It also investigates the tax losses associated with these shadow economic activities in all three countries. The Multiple Indicators and Multiple Causes (MIMIC) model is applied and uses time series data covering the period 1990-2019. The key findings show that the sizes of the shadow economies of the Czech Republic, Hungary and Poland are 10.44, 11.18 and 20.47\% respectively. The results also show that the average size of the shadow economies between 1990-2019 was $14.92 \%$ in the Czech Republic, $18.72 \%$ in Hungary and $22.85 \%$ in Poland. The Czech Republic loses 3.13\% of tax revenue from goods and services and $2.83 \%$ from incomes and profits as a result of the shadow economy, while Hungary loses $5.05 \%$ of $\operatorname{tax}$ revenue from goods and services and $1.68 \%$ from incomes and profits. Poland loses $5.25 \%$ of tax revenue from goods and services and $4.34 \%$ from incomes and profits.
\end{abstract}

\section{KEYWORDS}

shadow economy, structural equation model, tax evasion, MIMIC model

JEL CODES

C39, C51, C82

\section{INTRODUCTION}

The term underground or shadow economy largely refers to activities in a country which involve the production of goods and services that are not covered in the official system. These activities

*Corresponding author. E-mail: dennis.nchor@mendelu.cz 
are experienced in all economies across the world but the share of such activities as a percentage of official GDP differs from country to country. Though their presence is largely seen as bad, they make positive contributions to the economies in which they are found in the form of income and alternative source of employment to a section of the labour force. The negative consequences of underground economies are the huge losses of government revenues and violations of labour, health and safety regulations (OECD 2017). Shadow economies also contribute to various forms of distortions in the labour market.

The definition of shadow economy includes all economic activities which are hidden from the authorities for monetary, regulatory, and institutional reasons. Monetary reasons include avoiding payment of taxes and all social security contributions. Regulatory reasons include avoiding governmental bureaucracy or the burden of regulatory procedures. Institutional reasons include corruption, the quality of political institutions and weak rule of law. For this study, shadow economies reflect mostly legal economic and productive activities that, if recorded, would contribute to national GDP. Therefore, the definition of shadow economy in this study tries to avoid illegal or criminal activities, do-it-yourself, or other household activities. Many definitions focus on the hidden nature of output and employment (see Gerxhani 2003; Hassan Schneider 2016; Schneider - Williams 2013).

Empirical research into the size and development of the global shadow economy has grown rapidly over the years (Feld - Schneider 2010; Schneider 2015, 2017; Williams - Schneider, 2016; Hassan - Schneider 2016). Shadow economies by nature are difficult to measure, as agents engaging in shadow economic activities try to remain undetected. This study focuses on the cases of three Visegrad countries: the Czech Republic, Hungary and Poland. The Visegrad group is a cultural and political alliance of four Central European countries: the Czech Republic, Hungary, Poland and Slovakia. All four countries are member states of the European Union (EU). Slovakia is excluded due to data challenges on key variables. The need for information about the extent of the shadow economies and their developments over time in the three Visegrad countries is motivated by the topic's political and economic relevance. Moreover, total economic activity including official and unofficial production of goods and services is essential in the design of economic policies that respond to fluctuations and economic development over time and across space. Furthermore, the size of the shadow economy is a core input to estimate the extent of tax evasion and thus for decisions on its adequate control.

The paper therefore seeks to shed light on the extent of shadow economic activities in the three mentioned Visegrad countries. This includes an estimation of the size of the shadow economies as a percentage of official GDP, a determination of the factors that contribute to the growth of such activities and an assessment of the tax losses associated with these shadow economic activities.

The study applies the Multiple Indicators and Multiple Causes (MIMIC) model as explained by Schneider (2016). In this model, the size of the shadow economy is represented by a latent variable, with its causes called observed variables and indicators called measurement variables. The latent variable is used in a system of two equations, as the dependent variable with its causes and as the explanatory variable for the indicator variables. The equations are estimated simultaneously, and the fitted values of the latent variable are used to compute an estimate of the size of the shadow economy as a share of GDP.

The study considers variables such as corruption, the rate of unemployment, low GDP per capita, high tax burdens, higher social security contributions, poor business regulations, 
complicated and bureaucratic business registration procedures, self-employment activities, among others, as the determinants of the shadow economies in the three Visegrad countries. The presence of a shadow economy is indicated by the following variables: high cash outside the banking system, low labour force participation in the official system and high GDP growth. The study covers a period between 1990 and 2019 and applies time series data obtained from the World Bank Country Indicators.

The structure of the study is as follows: following this introduction, the second section deals with the review of literature on the study of shadow economies and methods applied. The third section focuses on the methodology of the paper, and also specifies the data, data sources and data transformation techniques. The fourth section shows the interpretation and discussion of the results, while the final section focuses on drawing conclusions to the key findings of the paper.

\section{LITERATURE REVIEW}

The Visegrad Group is made up of four Central European countries that have relations in the area of business, and other economic activities. The history of the Visegrad Group is traced back to the 14th century. The four countries in this group are commonly referred to as the V4. The current population of the three countries covered in this paper is estimated to be 10.6 million in the case of the Czech Republic, 9.7 million people for Hungary and 37.9 million for Poland. The rate of taxes on goods and services is about $21 \%$ in the Czech Republic, 27\% in Hungary and $23 \%$ in Poland. Corporate taxes or taxes on incomes and profits of companies is about $19 \%$ in the Czech Republic, 9\% in Hungary and 19\% in Poland. The rate of unemployment is about 2\% in the Czech Republic, 3.4\% in Hungary and 3.3\% in Poland according to the World Development Indicators (2019). Real GDP per capita in the Czech Republic is about US\$17,620, Hungary US $\$ 12,560$ and Poland US\$12,430 (World Development Indicators 2019). The labour force participation rate in the official economy is about $60 \%$ in the Czech Republic and $56 \%$ in both Hungary and Poland according. The percentage of self-employment is about 16, 10 and $20 \%$ in the Czech Republic, Hungary and Poland respectively. The Czech Republic has a better index for start-up procedures for business registration (9), than Hungary (7) and Poland (5). These differences may affect the dynamics of the shadow economies in the respective countries, and are reviewed in this section.

Shadow economic activities are activities and incomes earned through ways that circumvent government regulation, taxation or observation. More narrowly, the definition of shadow economies includes monetary and non-monetary transactions of a legal nature. This captures all productive economic activities that would generally be taxable when reported to the tax authorities. Such activities are deliberately concealed from public authorities to avoid payment of income taxes, value added or other taxes and social security contributions, or to avoid compliance with certain legal labour market standards such as minimum wages, maximum working hours, or safety standards and administrative procedures. The shadow economy thus, focuses on productive economic activities that would normally be included in national accounts, but which remain underground due to tax or regulatory burdens. Although such legal activities would contribute to a country's value added, they are not captured in national accounts. 
The size of the shadow economy in each country depends on various elements. Literature highlights specific causes and indicators of shadow economies. According Enste (2018), shadow economies in Central and Eastern European countries are caused by incompetent regulatory institutions, weak regulations and bureaucratic business registration procedures. Enste (2010) focused on institutional determinants of shadow economies stating that the quality and quantity of governmental regulation are the most important factors determining the size of the shadow economy. Studies that found regulatory burdens as a common cause of shadow economies of countries include Dabla-Norris et al. (2008) and Oviedo et al. (2009).

High tax burden is also another notable cause of growth in the size of shadow economies of countries. Studies that attribute the presence of shadow economies to high tax burdens include Tafenau et al. (2010), Schneider and Williams (2013) as well as Hassan and Schneider (2016). Other studies, including De Gijbel (1984), Lemieux et al. (1994) and Enste (2003), associate the growth of shadow economies with high early retirement ages. They suggest that the reduction of the working hours for retired individuals drives employees to devote some time to work in the informal sector.

In most studies, low GDP per capita is mentioned as one of the common causes of shadow economies (Alanon - Gomez-Antonio 2005; Herwartz et al. 2015; Petersen et al. 2010; Putninš Sauka 2011; Schneider et al. 2010; Thiesen 2003). They concluded that low GDP per capita is a high motivating factor that encourages individuals and businesses to participate in shadow economies.

Feld and Schneider (2010) and Schneider and Williams (2013) attribute the increasing presence of shadow economic activities to growing self-employment. Similarly, Bordignon and Zanardi (1997) concluded that a high self-employment rate leads to a parallel shadow economy increase insofar as these workers can collaborate with their customers to avoid indirect taxes. They found that it is easier for large firms to employ irregular workers because they have fewer internal and external audit control.

The quality of governance has also been associated with shadow economies. Quality of governance minimizes the growth of shadow economies and vice versa ceteris paribus. Examples of studies that focused on this factor include Johanson et al. (1998), Dreher and Schneider (2009), Dreher et al. (2009), Buehn and Schneider (2012), Teobaldelli (2011), Amendola and Dell'Anno (2010) and Schneider and Williams (2013). Studies by Alm and Gomez (2008), Stiglitz et al. (2010), and Torgler and Schneider (2009) considered sociocultural dimensions of society in the estimation of shadow economies. Further studies that captured the impact of sociocultural factors include Tsakumis et al. (2007) and Petrakis (2014).

\section{METHODOLOGY}

This study employs the Multiple Indicators and Multiple Causes model. The goal of the study is threefold: first to determine the factors that cause shadow economic activities in the Czech Republic, Hungary and Poland; second, to estimate the size of the shadow economies as a percentage of official GDP; and third, to assess the extent of tax revenue losses associated with the shadow economic activities. Various methods have been employed to study shadow economies of countries. The two common methods are the MIMIC approach (Schneider - Enste 2000; Buehn - Schneider 2012) and the Currency Demand Approach (Ariyo - Bekoe 2011; Faal 
2003). The study uses shadow economy, hidden economy and informal economy interchangeably.

As a variant of Simultaneous Equation Models, the MIMIC model has two parts: the structural equation part and the measurement part. The structural equation part estimates the relationship between the causal variables and the latent variable (the shadow economy). The measurement part estimates the relationship between the shadow economy (latent variable) and the indicator variables. The structural equation model is presented in Eq. (1). In this model, $\eta_{t}$ is the latent variable (the shadow economy) and $\alpha_{1}, \alpha_{2}, \ldots, \alpha_{7}$ are the model coefficients. Symbols $X_{1}, X_{2}, \ldots, X_{7}$ denote exogenous causal variables determining the size of the latent variable. These variables include GDP per capita (measured in constant US\$), taxes on goods and services (\%), taxes on incomes and profits (\%), time required for business registration, unemployment rate (\%), self-employment (\%) and social security contributions (US\$). The latent variable is directly unobserved, but it can be estimated from the MIMIC model. Statistically significant coefficients imply that the variables are the determinants of the shadow economy.

$$
\eta_{t}=\alpha_{1} X_{1 t}+\alpha_{2} X_{2 t}+\alpha_{3} X_{3 t}+\alpha_{4} X_{4 t}+\alpha_{5} X_{5 t}+\alpha_{6} X_{6 t}+\alpha_{7} X_{7 t}+\varepsilon_{t}
$$

Simultaneously, the measurement model estimates the statistical significance of the indicator variables of the shadow economy. These variables include the labour force participation rate (\%) in the official system, money outside the banking system (US\$) and the GDP growth rate (\%). If the estimated relationship is significant at the $5 \%$ significance level, it confirms the reliability of the variables as indicators of the presence of the shadow economy. The measurement model is given by Eq. (2).

$$
y_{t}=\beta \eta_{t}+\varepsilon_{t}
$$

where $y_{t}=\left(y_{1}, y_{2} \ldots, y_{n}\right)$ is a $(1 \times n)$ vector of the indicator variables, $\beta$ represents the regression coefficients and $\varepsilon_{t}$ is a $(1 \times n)$ vector of errors satisfying white noise.

First, for each country, the MIMIC model is specified, and its parameters are subsequently estimated by the method of Maximum Likelihood (ML). The ML technique is commonly used because it provides the estimates of models simultaneously (see Kline 2011; Chou - Bentler 1995). For example, given $\left\{X_{1}, X_{2}, \ldots, X_{n}\right\}$, a random sample is derived from multivariate normal distribution $N\left(\mu_{0}, \sum_{0}\right)$ to obtain $\Sigma_{0}=\sum\left(\theta_{0}\right)$, assumed there is population matrix function with $\Sigma_{0}, q \times 1$ size and $\theta_{0}$ is an unknown parameter. The ML function can be defined as in Eq. (3).

$$
F_{\mathrm{ML}}(\theta)=\log |\Sigma(\theta)|+\operatorname{tr}\left(S \Sigma(\theta)^{-1}\right)-\log |S|-p
$$

The sample covariance matrix is denoted by $S$ and the covariance matrix of the hypothesised model is represented by $\Sigma\left(\theta_{0}\right)$, the trace matrix is represented by $t r$ and $p$ denotes the number of variables (Lee 2007). The data used is annual time series thus, the study performs unit root test to determine whether variables are stationary or not using the Augmented Dickey-Fuller test (Dickey - Fuller 1979). The test results show that variables are stationary only after first order differences. All variables are therefore differenced. The general structure of the MIMIC model is illustrated in Fig. 1.

Equation (4) shows the estimation of the MIMIC index. $\widehat{\eta}_{t}$ represents the calculated MIMIC index at a given time $t$; it is the estimate of the shadow economy as a percentage of the official 


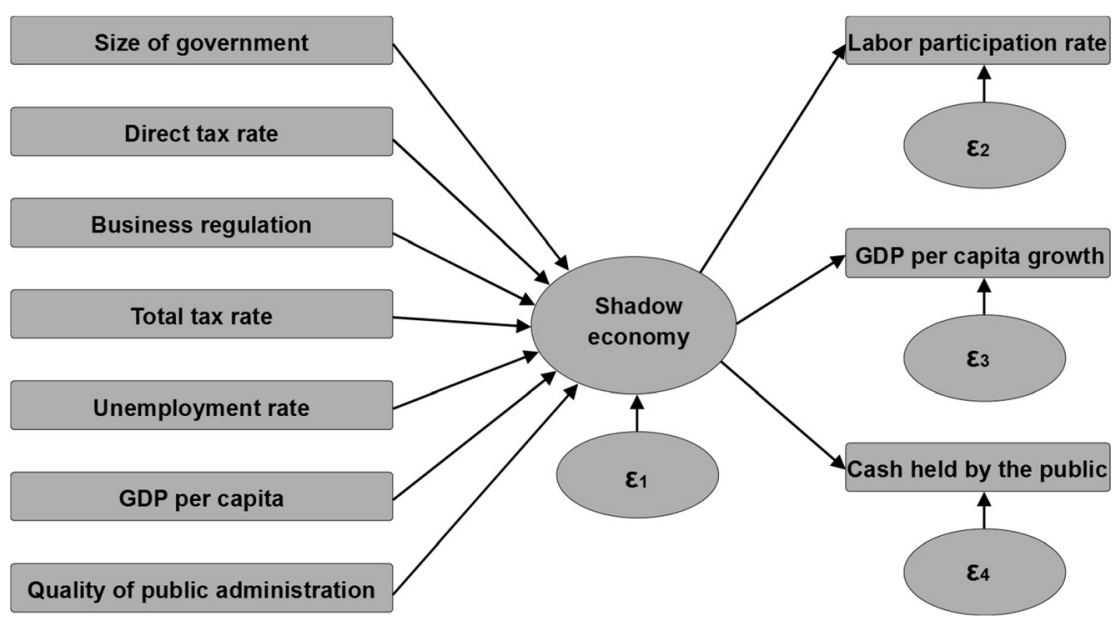

Fig. 1. Structure of the MIMIC model

Source: Nchor and Adamec (2015).

economy. $\tilde{\eta}_{t}$ is the estimated value of the latent variable at time $t . \tilde{\eta}_{1990}$ is the estimate of the shadow economy in the base year 1990 and $\eta_{1990}^{*}$ is the exogenous estimate of the shadow economy in 1990. Exogenous shadow economy is the exterior estimate, i.e. base value of the shadow economies in 1990, derived for each country as the average size of the shadow economy from several previous studies. The exogenous shadow economy values for $\tilde{\eta}_{1990}$ for the Czech Republic, Hungary and Poland are 18.4, 24.4 and 27.2\% respectively (see Schneider et al. 2010).

The cause and indicator variables provided may slightly differ among models for specific countries.

$$
\widehat{\eta}_{t}=100 \frac{\tilde{\eta}_{t}}{\tilde{\eta}_{1990}} \eta_{1990}^{*}
$$

The study also estimates the size of tax losses as a percentage of GDP in the Czech Republic, Hungary and Poland. The estimation begins with the average size of the shadow economies of the three countries for the period 1990-2019. Given the estimation of the average sizes of the shadow economies, the study finds GDP of the shadow economy. GDP of the shadow economy is calculated as a multiplication of the shadow economy index by official GDP. The average tax rates on goods and services and on incomes and profits are then applied on the GDP of the shadow economy to determine the amount of tax revenue losses.

During the diagnostic stage, the study verifies parameter significance $(\alpha=0.05)$ and ensures that the estimates from the structural equations model and the measurement model meet the criteria of good fit (StataCorp 2015). In this regard, the results of the MIMIC model are verified using certain key set of test statistics: standardized root mean squared residual (SRMR), the root mean squared error of approximation (RMSEA), the comparative fit index (CFI) and the coefficient of determination (CD). The SRMR is an index of the average of standardized residuals between the observed and the hypothesised covariance matrices (Chen 2007). SRMR is 
Table 1. MIMIC model for the Czech Republic

\begin{tabular}{|c|c|c|c|c|}
\hline Model & Variable & Coefficient & Std. Err. & $P>z$ \\
\hline \multicolumn{5}{|c|}{ Structural } \\
\hline & L1 & & & \\
\hline & GDP per Capita & -1 (constr.) & & \\
\hline & Social Security Contributions & 0.90 & 0.41 & 0.03 \\
\hline & Unemployment & 0.24 & 0.07 & 0.00 \\
\hline & Self-employment & 0.30 & 0.13 & 0.03 \\
\hline \multicolumn{5}{|c|}{ Measurement } \\
\hline & GDP per Capita & & & \\
\hline & L1 & 1 (constr.) & & \\
\hline & Constant & -0.39 & 0.10 & 0.00 \\
\hline & LFPR & & & \\
\hline & L1 & 0.343 & 0.012 & 0.00 \\
\hline & Constant & 0.64 & 0.59 & 0.28 \\
\hline & Money & & & \\
\hline & L1 & 0.61 & 0.27 & 0.00 \\
\hline & Constant & -1.34 & 0.80 & 0.10 \\
\hline
\end{tabular}

Note: L1 represents the latent variable (shadow economy).

Source: author.

interpreted as the indicator of good fit when the value it produces is lower than 0.05 (Kline 2011; Lacobucci 2010). RMSEA measures the difference between the covariance matrix of every degree of freedom and the hypothesised covariance matrix. RMSEA indicates a good fit when the value it produces lies between 0.05 and 0.08 . The fit is neither good or bad when the value lies between 0.08 and 0.10. According to $\mathrm{Hu}$ and Bentler (1999), RMSEA smaller than 0.06 will suffice for good model fit. CFI, which is also used to measure model fit, is an incremental fit index. It shows the degree to which the main model is superior to the alternative model which is established with manifest covariance matrix (Chen 2007). CFI produces values which range from 0 to 1 . Higher values indicate good fit (Schermelleh-Engel - Moosbrugger 2003). Estimation of the MIMIC model and the follow-up diagnostics were completed with STATA 15. The annual time series analysed in this study were taken from the World Bank country indicators.

\section{RESULTS}

This section interprets and discusses the findings of the study. The results include the structural equation models and the measurement models. Significant indicator variables show the exact 
Table 2. MIMIC model for Hungary

\begin{tabular}{|l|c|c|c|c|}
\hline Model & Variable & Coefficient & Std. Err. & P > z \\
\hline Structural & L1 & & & \\
\hline & GDP per Capita & -1 (constr.) & & \\
\hline & Indirect taxes & 0.61 & 0.21 & 0.00 \\
\hline & Corporate taxes & 0.19 & 0.08 & 0.02 \\
\hline & Unemployment & 0.45 & 0.12 & 0.00 \\
\hline Measurement & & & & \\
\hline & GDP per Capita & & & \\
\hline & L1 & 0.01 (constr.) & & 0.00 \\
\hline & Constant & 3.05 & 0.97 & 0.00 \\
\hline & LFPR1 & & 0.12 & 0.55 \\
\hline & L1 & 0.51 & 0.14 & 0.92 \\
\hline
\end{tabular}

Note: L1 represents the latent variable (shadow economy).

Source: author.

factors causing shadow economic activities in the respective countries. Significant measurement variables show the exact factors used to measure the presence of shadow economic activities.

\subsection{The determinants of the shadow economies in the Czech Republic, Hungary and Poland}

Table 1 shows the results for the Czech Republic. It shows that shadow economic activities are caused by GDP per capita, social security contributions, the rate of unemployment and the rate of self-employment activities. The relationship between GDP per capita and the shadow economy is negative, indicating that lower GDP per capita leads to higher shadow economic activities. The result for social security contributions also shows a positive impact, meaning that the higher the burden of social security contributions, the higher the shadow economy. Unemployment has a positive relationship with the shadow economy, showing that higher rates of unemployment push people into shadow economic activities. The relationship between selfemployment and the shadow economy is also positive, implying that higher unemployment leads to higher shadow economic activities. 
Table 3. MIMIC model for Poland

\begin{tabular}{|c|c|c|c|c|}
\hline Model & Variable & Coefficient & Std. Err. & $P>z$ \\
\hline \multicolumn{5}{|c|}{ Structural } \\
\hline & L1 & & & \\
\hline & GDP per Capita & -0.01 & & \\
\hline & SPTRB & 0.51 & 0.19 & 0.01 \\
\hline & Indirect taxes & 1.00 & & \\
\hline & Corporate taxes & 0.12 & 0.09 & 0.02 \\
\hline & Unemployment & 0.20 & 0.1 & 0.05 \\
\hline & Self-employment & 0.05 & & \\
\hline \multicolumn{5}{|c|}{ Measurement } \\
\hline & GDP per Capita & & & \\
\hline & L1 & 0.01 & & \\
\hline & Constant & 4.07 & 0.36 & 0.00 \\
\hline & LFPR & & & \\
\hline & L1 & -1.06 & 0.52 & 0.04 \\
\hline & Constant & 58.19 & 1.21 & 0.00 \\
\hline & Money & & & \\
\hline & L1 & 1.00 & & \\
\hline & Constant & 0.76 & 0.28 & $<0.01$ \\
\hline
\end{tabular}

Note: SPTRB represents start-up procedures to register a business, L1 represents the latent variable (shadow economy).

Source: author.

The MIMIC model results of Hungary are shown in Table 2. It reveals that shadow economic activities are caused by GDP per capita, taxes on goods and services, corporate taxes (taxes on incomes and profits) and unemployment. GDP per capita has a negative relationship with the shadow economy, indicating that lower GDP per capita causes people to venture into shadow economic activities. The results also show that the burden of taxes both on goods and services and on company profits causes a rise in shadow economic activities. The final determinant of shadow economic activities is the unemployment rate, which shows that a higher rate of unemployment leads to higher rates of shadow economic activities.

The MIMIC model results of Poland are shown in Table 3. The results show that activities of the shadow economy are caused by GDP per capita, start-up procedures to register a business (SPRTB), taxes on goods and services, corporate taxes and the unemployment rate. The resulting signs of the coefficients show that lower GDP per capita causes higher shadow economic activities than in the Czech Republic and Hungary. It also shows that more complicated and 
Table 4. Goodness of fit statistics

\begin{tabular}{|l|l|}
\hline Fit statistic & Value \\
\hline Czech Republic & 0.00 \\
\hline RMSEA & 0.00 \\
\hline Pclose & 1.00 \\
\hline CFI & 0.026 \\
\hline SRMR & 0.553 \\
\hline CD & \\
\hline Hungary & 0.00 \\
\hline RMSEA & 0.00 \\
\hline Pclose & 1.00 \\
\hline CFI & 0.019 \\
\hline SRMR & 0.74 \\
\hline CD & \\
\hline Poland & 0.04 \\
\hline RMSEA & 0.00 \\
\hline Pclose & 1.00 \\
\hline CFI & 0.008 \\
\hline SRMR & 0.57 \\
\hline CD & \\
\hline
\end{tabular}

Note: Pclose refers to the probability of RMSEA $\leq 0.05$.

Source: author.

bureaucratic procedures for business registration (SPRTB) lead to higher shadow economic activities. Tax burden is seen to have a positive impact on shadow economies. A positive relationship is established for both taxes on goods and services as well as corporate taxes. The unemployment rate has a positive relationship with the shadow economy, indicating that higher unemployment causes higher shadow economic activities.

\subsection{Goodness of fit statistics}

The MIMIC model verification for the Czech Republic, Hungary and Poland show that the estimated coefficients meet the criteria for interpretation. The estimated model fit statistics are shown in Table 4. The study measures the quality of the model using values of the RMSEA, SRMR, CFI and the CD. The SRMR values obtained for all countries are lower than 0.05 , thus indicating a good fit. Using the RMSEA, the values for all countries are less than 0.06 , thus also indicating good model fit. The CFI values for all countries are 1, indicating good fits. CD measures the percentage of the model explained by the explanatory variables. In the case of the 
Czech Republic, the CD is 0.55 showing that the model variables explain $55 \%$ of the shadow economy. The value is 0.74 in the case of Hungary showing that $74 \%$ of the variation in the shadow economy is explained by the variables. The coefficient of determination for Poland is 0.57 showing that $57 \%$ of the variation in the shadow economy of Poland is explained by the model variables.

\subsection{The estimated size of the shadow economies as a percentage of GDP}

Fig. 2 shows the sizes of the shadow economies of the Czech Republic, Hungary and Poland as a percentage of official GDP. The shadow economies are smaller in the Czech Republic and Hungary than in Poland. The size of the shadow economy of the Czech Republic was $10.44 \%$ of official GDP in 2019, 11.18\% in Hungary and 20.47\% in Poland. The size of the shadow economies of all countries have declined relatively overtime. The global financial crises affected the shadow economy of the Czech Republic largely, as its shadow economy reached its peak in that year, then declined afterwards.

Fig. 3 shows the visualisation of the average size of the shadow economies covering the period 1990-2019. It shows that even though the 2019 values of the shadow economies are much lower (10.44\% for the Czech Republic, $11.18 \%$ for Hungary and $20.47 \%$ for Poland), the average for the entire period is higher (14.92\% for the Czech Republic, $18.72 \%$ for Hungary and $22.85 \%$ for Poland), largely influenced by the higher initial shadow economy figures recorded for all countries.

\subsection{Average tax revenue losses from shadow economic activities}

Fig. 4 shows tax revenue losses as a percentage of official GDP in the Czech Republic, Hungary and Poland. Two types of tax revenues are considered. The first is the revenue generated from taxes on goods and services and the second is the revenue from taxes on incomes and profits of companies (corporate taxes). The Czech Republic loses $3.13 \%$ of tax revenues from goods and

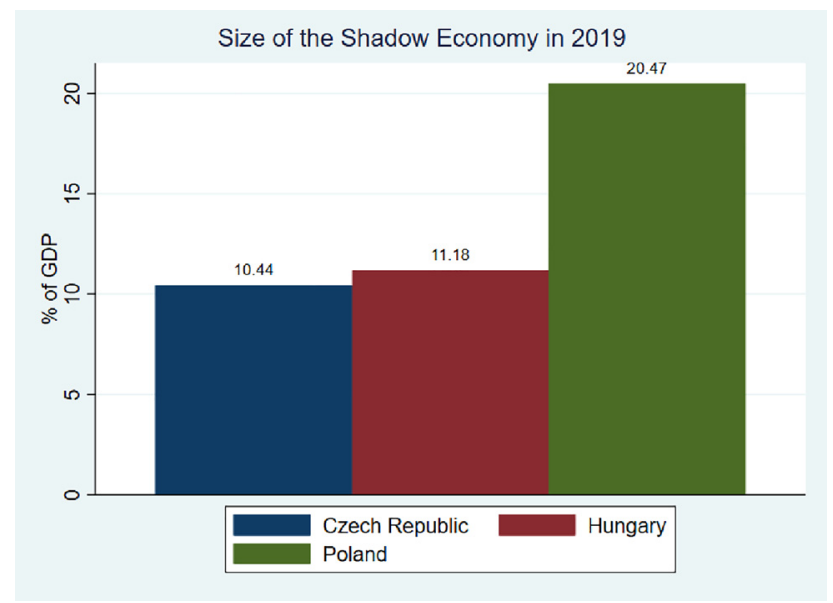

Fig. 2. The size of the shadow economies in 2019

Source: author. 


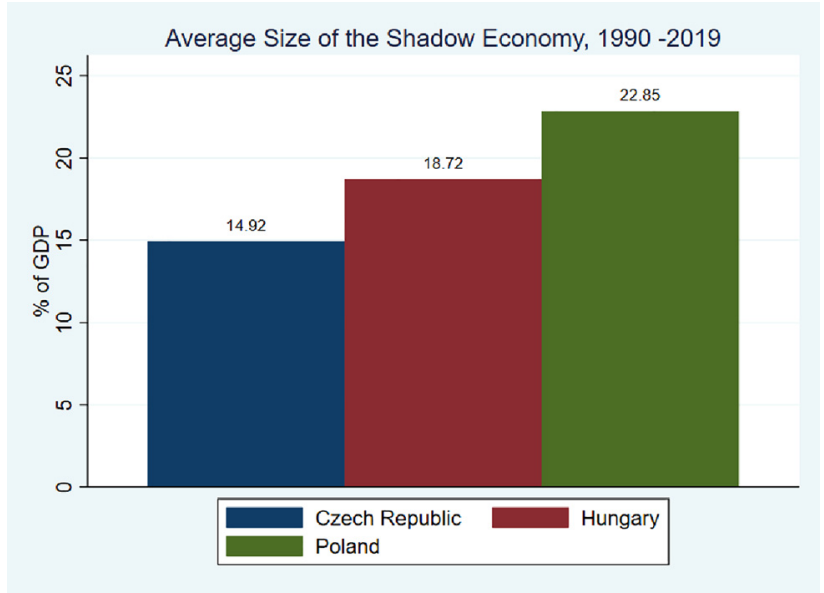

Fig. 3. The average size of the shadow economies from 1990 to 2019 Source: author.

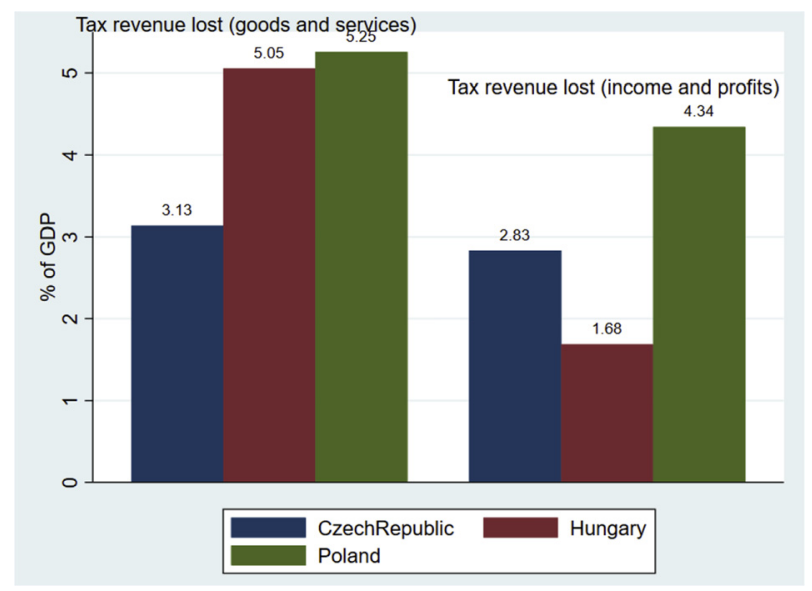

Fig. 4. Tax losses from the shadow economy Source: author.

services and $2.83 \%$ from company incomes and profits. Hungary loses 5.05\% of tax revenues from goods and services as well as $1.68 \%$ from incomes and profits. Poland loses $5.25 \%$ of tax revenues from goods and services and $4.34 \%$ from company incomes and profits. All figures are a percentage of official GDP.

\subsection{Discussion}

This study observes that the determinants of shadow economic activities in the three Visegrad countries are related. In other words, there are common causes to a large extent, even though 
one or two factors vary. The study finds that GDP per capita, burdens of social security contributions, unemployment and self-employment activities are the causes of the shadow economy of the Czech Republic. The study also finds that GDP per capita, taxes on goods and services, taxes on incomes and profits (corporate tax) as well as the rate of unemployment are the determinants of the shadow economy of Hungary. In the case of Poland, the study observes that GDP per capita, start-up procedures to register a business, taxes on goods and services, taxes on incomes and profits, self-employment as well as the unemployment rate cause shadow economic activities. The study observes that GDP per capita and the rate of unemployment are common causes of the shadow economies in all three Visegrad countries.

The findings show a negative relationship between GDP per capita and shadow economy in all three countries, indicating that lower GDP per capita leads to higher shadow economic activities and vice versa ceteris paribus. The result for social security contributions shows a positive impact meaning that the higher the burden of social security contributions, the higher the motivation to participate in the shadow economy. Taxes on goods and services are seen to also have a positive relationship with the shadow economy, indicating that higher taxes lead to more shadow economic activities. The effect of unemployment is also positive on the shadow economy, indicating that a growing rate of unemployment leads to growing shadow economic activities. Self-employment is only statistically significant determinant of the shadow economy in the Czech Republic. It also has a positive relationship, indicating that the larger the growth of self-employment activities, the higher the hidden economy. The results also show that the burden of taxes on company profits causes a rise in shadow economic activities. Another determinant unique to the case of Poland is the start-up procedures for registering a new business. More complicated and bureaucratic procedures for business registration lead to higher shadow economic activities.

The findings on GDP per capita are similar to the conclusions of Porta and Shleifer (2008), who found that countries with higher productivity typically have a better allocation of resources within the economy and so smaller informal sectors. This conclusion is also supported by the findings of Herwartz et al. (2015) and Petersen et al. (2010). The findings on start-up procedures for the registration of businesses are similar to the conclusions of Enste (2018) who concluded that the shadow economies in Central and Eastern European countries are caused by incompetent regulatory institutions, weak regulations and bureaucratic business registration procedures. The conclusion of this study on the tax burden and the shadow economy are similar to that of Tafenau et al. (2010) who showed that shadow economies are caused by the presence of high tax burdens.

The conclusion of this study on the relationship between unemployment and the shadow economy are similar to the findings of Davidescu et al. (2015) and Mauleón and Sardà (2017), who concluded that higher levels of unemployment correlate with higher shares of shadow economic activities. With regards to self-employment, this study concludes that more selfemployment activities indicate more shadow economic activities in all three countries. This is supported by the findings of the ILO, (2014) as well.

The findings on the size of the shadows economies are similar to those of Medina and Schneider (2018), who found the average shadow economy of the Czech Republic to be 14.1\%, Hungary, 22.4\% and Poland 22.2\%. They also found the shadow economies of other European countries to be $8.93 \%$ in Austria, $29.17 \%$ in Bulgaria, and $30.14 \%$ in Romania. They estimated the average size of the shadow economies of advanced countries to be $15.8 \%$. Similarly, Hassan 
and Schneider (2016) studied shadow economies for advanced economies and found that the average size is about $20.5 \%$ of official GDP.

With regards to tax evasion, the results are compared with the results of Nchor and Konderla (2016) who estimated the tax loss due to shadow economic activities in the Czech Republic to be 7.2\%. Similarly, Buehn and Schneider (2016) estimated the percentage of tax evasion from shadow economic activities for 38 OECD countries and concluded that the average size of tax evasion over the period 1999 to 2010 was $3.2 \%$ of official GDP. In their study, Mexico and Turkey had the highest average values of about 6.8 and $6.7 \%$ respectively, while the United States and Luxembourg had the lowest average tax evasion rates with 0.5 and $1.3 \%$, respectively.

\section{CONCLUSIONS}

The study finds that the size of tax evasion by each country relates to the rate of selfemployment activities. For example, self-employment activities are higher in the Czech Republic and Poland and that corresponds with higher tax evasion in both countries. Self-employment also proves to be a statistically significant determinant of the shadow economy in the two countries. It is therefore not out of place to focus attention on these activities. The study also finds that the size of the tax loss is proportional to the size of the tax burden. Countries with higher tax burdens experienced higher tax evasion. An example is Poland with a high rate of value added tax and high rate of tax on incomes and profits. The study's recommendation here is that the tax burden should be reduced to rope in all business activities in the formal system.

Another key finding of this study is that difficult and bureaucratic business registration procedures cause growth in shadow economic activities by pushing business owners to avoid going through such procedures. The by-product of such cases is an unnecessary growth in the size of the shadow economy. Registration procedures for businesses should be sanitised with easy access to registration points and lower cost of registration. In more practical cases, a conducive environment should be created for foreign business investors with regards to personnel at the registration points. It is problematic if registration officials are not willing to speak common languages that are understandable to business owners. Language barrier at business registration points and tax administration offices should therefore be of paramount interest to governments in their bid to minimize shadow economic activities.

For all countries, the rate of unemployment proves to be a statistically significant determinant of the shadow economy. Unemployment exists in every country, but its impact on shadow economic activities will largely depend on social policies that provide sources of living for the unemployed. There is also the argument by some authors about the early retirement age, which tends to render labour redundant, thus driving them into such activities. The recommendation is to provide social safety nets for the growing numbers of unemployed. The retirement age should also be increased to reduce the number of idle labour available to participate in the shadow economy.

The limitation of the study is with regards to the MIMIC model. The model does not address the illegal economy, hence it does not cover the whole magnitude of the unofficial economy. However, other popular methods for the estimation of shadow economies do not seem to have better alternatives to the measurement of the illegal economy either. Some key determinants of shadow economic activities are not included in the study due to lack of data availability. 
Examples of such variables include data on corruption, business regulation and non-official remittances.

\section{REFERENCES}

Alanon, A. - Gomez-Antonio, M. (2005): Estimating the Size of the Shadow Economy in Spain: A Structural Model with Latent Variable. Applied Economics 37(9): 1011-1025.

Alm, J. - Gomez, J. L. (2008): Social Capital and Tax Morale in Spain. Economic Analysis and Policy 38(1): 73-87.

Amendola, A. - Dell'Anno, R. (2010): Institutions and Human Development in the Latin America Shadow Economy. Estudios en Derecho y Gobierno 3(1): 9-25.

Ariyo, A. - Bekoe, W. (2011): Currency Demand, the Underground Economy and Tax Evasion: The Case of Nigeria. Journal of Monetary and Economic Integration 11(2): 129-157.

Bordignon, M. - Zanardi, A. (1997): Tax Evasion in Italy. Giornale Degli Economistie Annali di Economia 56(3-4): 169-210.

Buehn, A. - Schneider, F. (2012): Size and Development of Tax Evasion in 38 OECD Countries: What Do We (not) Know? University of Linz Department of Economics Discussion Paper, June 2013.

Buehn, A. - Schneider, F. (2016): Size and Development of Tax Evasion in 38 OECD Coutries: What do we (not) know? Journal of Economics and Political Economy 3(1).

Chen, F. F. (2007): Sensitivity of Goodness of Fit Indexes to Lack of Measurement Invariance. Structural Equation Modeling 14(3): 464-504.

Chou, C. P. - Bentler, P. M. (1995): Estimates and Tests in Structural Equation Modeling. In: Hoyle, R. H. (ed.): Structural Equation Modelling: Concepts, Issues, and Applications. SAGE Publications, pp. 37-55.

Dabla-Norris, E. - Gradstein, M. - Inchauste, G. (2008): What Causes Firms to Hide Output? The Determinants of Informality. Journal of Development Economics 85(1): 1-27.

Davidescu, A. - Strat, V. A. - Paul, A. M. (2015): Revisiting the Size of Romanian Informal Economy Using the Gutmann Approach. Procedia Economics and Finance 23: 1037-1045.

De Gijsel, P. (1984): Ökonomische Theorie des Schwarzarbeitsangebots und der Mehrfachbeschäftigung. Schattenwirtschaft. Wirtschafts-und Sozialwissenschaftliche Aspekte. Internationale Erfahrungen. Göttingen: Vandenhoeck \& Rubrecht.

Dickey, D. A. - Fuller, W. A. (1979): Distribution of the Estimators for Autoregressive Time Series with a Unit Root. Journal of the American Statistical Association 74(366): 427-431.

Dreher, A. - Kotsogiannis, C. - McCorriston, S. (2009): How Do Institutions Affect Corruption and the Shadow Economy?. International Tax and Public Finance 16(4): 773-796.

Dreher, A. - Schneider, F. (2009): Corruption and the Shadow Economy: An Empirical Analysis. Public Choice 144(2): 215-277.

Enste, D. H. (2003): Shadow Economy and Institutional Change in Transition Countries. In: Belev, B. (ed.) The Informal Economy in the EU Accession Countries: Size, Scope, Trends and Challenges to the Process of EU Enlargement. Sofia: Centre for the Study of Democracy, pp. 81-113.

Enste, D. H. (2018): The Shadow Economy in Industrial Countries. IZA World of Labor 127(2).

Faal, E. 2003: Currency Demand, the Underground Economy and Tax Evasion - The Case of Guayana. IMF Working Paper 07/2003.

Feld, L. P. - Schneider. F. (2010): Survey on the Shadow Economy and Undeclared Earnings in OECD Countries. German Economic Review 11(2): 109-149. 
Gerxhani, K. (2003): The Informal Sector in Developed and Less-Developed Countries: A Literature Survey. Public Choice 114(3-4): 295-318.

Hassan, M. - Schneider, F. (2016): Size and Development of the Shadow Economies of 157 Worldwide Countries: Updated and New Measures from 1999 to 2013. Journal of Global Economics 4(3).

Herwartz, H. - Tafenau, E. - Schneider, F. (2015): One Share Fit All? Regional Variations in the Extent of the Shadow Economy in Europe. Regional Studies 49(9): 1575-1587.

Hu, L. T. - Bentler, P. M. (1999): Cutoff Criteria for Fit Indexes in Covariance Structure Analysis: Conventional Criteria versus New Alternatives. Structural Equation Modeling: A Multidisciplinary Journal 6(1): 1-55.

ILO (2014): Country Profiles. http://www.ilo.org/ilostat/faces/home/statisticaldata/ContryProfileId? _afrLoop=436335912758103\#\%40\%3F_afrLoop\%3D436335912758103\%26_adf.ctrl-state\%3D15j2r4wmvg $163 /$, accessed 14/12/2015.

Johnson, S. - Kaufmann, D. - Zoido-Lobatón, P. (1998): Regulatory Discretion and the Unofficial Economy. The American Economic Review 88(2): 387-392.

Kline, R. B. (2011): Principles and Practice of Structural Equation Modeling. 3rd Edition. New York: The Guilford Press.

Lacobucci, D. (2010): Structural Equations Modeling: Fit Indices, Sample Size, and Advanced Topics. Journal of Consumer Psychology 20(1): 90-98.

Lee, S. Y. (2007): Structural Equation Modeling: A Bayesian Approach. New York: John Wiley \& Sons.

Lemieux, T. - Fortin, B. - Frechette, P. (1994): The Effect of Taxes on Labour Supply in the Underground Economy. The American Economic Review 84(1): 231-254.

Mauleón, I. - Sardà, J. (2017): Unemployment and the Shadow Economy. Applied Economics 49(37): 37293740

Medina, L. - Schneider, F. (2018): Shadow Economies around the World: What Did We Learn Over the Last 20 years?. IMF Working Papers 18/17.

Nchor, D. - Adamec, V. (2015): Unofficial Economy Estimation by the MIMIC Model: The Case of Kenya, Namibia, Ghana and Nigeria. Acta Universitatis Agriculturae et Silviculturae Mendelianae Brunensis 63(6): 2043-2049.

Nchor, D. - Konderla, T. (2016): The Shadow Economy of Czech Republic and Tax Evasion: The Currency Demand Approach. Acta Universitatis Agriculturae Et Silviculturae Mendelianae Brunensis 64: 20812086.

OECD (2017): Shining Light on the Shadow Economy: Opportunities and Threats. https://www.oecd.org/ tax/crime/shining-light-on-the-shadow-economy-opportunities-and-threats.pdf, accessed 12/07/2018.

Oviedo, A. M. - Thomas, M. R. - Karakurum-Ozdemir, K (2009): Economic Informality: Causes, Costs, and Policies: A Literature Survey. Washington DC: World Bank Publications.

Petersen, H. G. - Thiesen, U. - Wohlleben, P. (2010). Shadow Economy, Tax Evasion and Transfer Fraud Definition, Measurement and Data Problems. Inter-national Economic Journal 24(4): 421-441.

Petrakis, P. E. (2014): Culture, Growth and Economic Policy. Berlin: Springer.

Porta, R. - Shleifer, A. (2014): Informality and Development. Journal of Economic Perspectives 28(3): 109126.

Putninš, T. J. - Sauka, A. (2011): The Size and Determinants of Shadow Economies in the Baltic States. Journal of Economics 11(2): 5-25.

Schermelleh-Engel, K. - Moosbrugger, H. (2003): Evaluating the Fit of Structural Equation Models: Tests of Significance and Descriptive Goodness-of-Fit Measures. Methods of Psychological Research Online 8(2): 23-74. 
Schneider, F. (2015): Schattenwirtschaft und Schattenarbeitsmarkt: Die Entwicklungen der vergangenen 20 Jahre. Perspektiven der Wirtschaftspolitik 16(1): 3-25.

Schneider, F. (2016): Comment on Feige's Paper Reflections on the Meaning and Measurement of Unobserved Economies: What Do We Really Know about the Shadow Economy?. Journal of Tax Administration 2(2): 82-92.

Schneider, F. (2017): Estimating a Shadow Economy: Results, Methods, Problems, and Open Questions. Open Economics 2017(1): 1-29.

Schneider, F. - Buehn, A. - Montenegro, C. E. (2010): New Estimates for the Shadow Economies All Over the World. International Economic Journal 24(4): 443-461.

Schneider, F. - Enste, D. H. (2000): Shadow Economies: Size, Causes, and Consequences. Journal of Economic Literature 38(1): 77-114.

Schneider, F. - Willams, C. C. (2013): The Shadow Economy. London: IEA.

STATACORP (2015): Stata Statistical Software: Release 12. College Station, TX: StataCorp LP.

Stiglitz, J. - Sen, A. K. - Fitoussi, J. P. (2010): Mismeasuring Our Lives: Why GDP Doesn't Add Up. The New Press.

Tafenau, E. - Herwartz, H. - Schneider, F. (2010): Regional Estimates of the Shadow Economy in Europe. International Economic Journal 24(4): 629-636.

Teobaldelli, D. (2011): Federalism and the Shadow Economy. Public Choice 146(3): 269-269.

Thiesen, U. (2003): The Impact of Fiscal Policy and Deregulation on Shadow Economies in Transition Countries: The Case of Ukraine. Public Choice 114: 295-318.

Torgler, B. - Schneider, F. (2009): The Impact of Tax morale and Institutional Quality on the Shadow Economy. Journal of Economic Psychology 30(2): 443-470.

Tsakumis, G. T. - Curatola, A. P. - Porcano, T. M. (2007): The Relation between National Cultural Dimensions and Tax Evasion. Journal of International Accounting, Auditing and Taxation 16: 131-147.

Williams, C. C. - Schneider, F. (2016): Measuring the Global Shadow Economy: The Prevalence of Informal Work and Labour. Cheltenham: Edward Elgar Publishing.

World Development Indicators (2019): The World Bank: DataBank. The World Bank https://databank. worldbank.org/source/world-development-indicators, (accessed 4 January 2018).

Open Access. This is an open-access article distributed under the terms of the Creative Commons Attribution-NonCommercial 4.0 International License (https://creativecommons.org/licenses/by-nc/4.0/), which permits unrestricted use, distribution, and reproduction in any medium for non-commercial purposes, provided the original author and source are credited, a link to the CC License is provided, and changes - if any - are indicated. 